\title{
THE EFFECTS OF POPULAR PRO-SOCIAL BEHAVIOUR CHILDREN ON PEERS AND SCHOOL ENVIRONMENT
}

\author{
Diah Ningrum \\ Early Childhood Education Program \\ STKIP Panca Sakti Bekasi, Jawa Barat, Indonesia \\ diahningrum@panca-sakti.ac.id
}

\begin{abstract}
The aims of the study were to find out the effects of popular pro-social children on peers and school environment. Mixed methods were used in the present study which had two phases; quantitative method and qualitative method. Peer matrix of peer nomination was used as data collection in quantitative, meanwhile interview was used in qualitative method. The results revealed that 5 popular children obtained from peer matrix of peer nomination were liked most by peers. The Results indicated that popular children gave effects on peers and school environment. Popular children influenced their peers and school environment in pro-social behaviour, leadership, and academic achievement. Meanwhile, besides in academic achievement homeroom teachers also agreed on the effects of popular children in pro-social behaviour.
\end{abstract}

Keywords: popular children; pro-social behavior; peers; school environment.

\section{INTRODUCTION}

Peers are important in children's life. The children's world will be fulfilled with happiness and joyfulness if they have friends and good relationship with peers. Through peers, children can share their ideas and opinions while they are doing the same activities together. From this relationship, children experiencing social skills are unconsciously developed, such as; how to communicate, how to behave, how to tolerate and compromise with others, how to understand, and how to respect each other. These social skills are hard to master if the children are isolated.

However, it is hard to imagine if children have no friends, and it is worst if they are not accepted by their peers. Their world will be quiet and there will be no challenges in dealing with their peers. Life will be boring because they cannot play and communicate freely. As an adult, we would like our children to mingle with their peers naturally. However, in reality, having relationship or be a part of a peer group is not that easy for some children. One of the reasons is because they do not know how to interact with others. Instead of showing positive behaviours such as being helpful and friendly, they send negative signals, such as aggressiveness and shyness which make their peers reject them.

It is interesting to know why this phenomenon happens since the school period is the time for children to interact with peers. The percentage of social interaction involving peers should increase (Rubin et al., 2006). According to Coie, Dodge and Coppotelli (1982), there is a relationship between peer status and peer acceptance. In other words, children are viewed based on their status that can determine them to be accepted or not to be accepted in the peer groups. To be accepted in peer groups is important for children adjustment particularly in the school and future social relationship in general (Birch and Ladd, 1996).

In the study of Coie et al. (1982), they proposed five (5) social status groups among children which are as follows; popular children, rejected children, controversial children, neglected, and average children. Popular children are mostly liked by others and they are usually associated with prosocial behaviours. In contrast, rejected children are mostly disliked and the characteristics described as anti-social 
children. The next social status groups are controversial and neglected children. Children who are controversial get the same number of nominations as liked and disliked. They have characters of popular and rejected children, they have leadership in peer groups; however, their leadership is used in creating anti-social behaviours. Meanwhile, the neglected children are mostly known because of their shyness and they have low social skills (Coie et al., 1982). Few peers nominate them for both liked and disliked. The last group is average children; children in this group get an average nomination for most liked and disliked (Coie et al., 1982).

From these five social status groups, popular children have many friends compared to other groups. This occurrence is mostly resulted from the attitude of the children themselves. Based on previous research, children with popular socio-metric status are associated with pro-social behaviour (Coie et al., 1982; Rubin et al., 2006). According to Eisenberg et al. (2006), pro-social behaviour is defined as voluntary action aimed to benefit another. This type of behaviour is an important factor in making quality interactions involving individuals and group.

Accordingly, popular pro-social children are viewed by their peers and teachers as cooperative, friendly, assertive, helpful, and constructive children (Rubin, Bukowski, and Parker, 2006). Therefore, popular children have a good relationship with peers and teachers. They always try to maintain good relationship with their peers and teachers. They can communicate and express what they feel in positive ways, and they want to listen as well (Rubin, Bukowski, and Parker, 2006). However, this pro-social behaviour is mostly found among girls compared to boys (Rys \& Bear, 1997). In addition, it is found that girls are more prosocial than her counterparts in the crosscultural tendency (Eisenberg et al., 2006). Thus, popular girls may show pro-social behaviour than popular boys.

Since popular pro-social children are also perceived as leaders (Coie, 1982), they tend to encourage their friends to behave in the same way. In others words, popular- prosocial children can influence their peers to become pro-social children or good students in the school context. For instance, popular pro-social children motivate their friends to study, to do their homework, to help other students and teachers, and etc. According to Younis (1987) in Eisenberg et al. (2006, p. 679), the acquisition of concepts and behaviour reflecting justice, sympathy and concern for another's well-being might be provided by peer interactions. It corresponds to the findings of other research that peer interactions are vital for the development of empathy, sympathy, and other-orientation (Eisenberg et al., 2006). Furthermore, the imposing of positive values is easier when peers have interaction with popular prosocial children who are viewed as leaders and role models. In social learning theory proposed by Bandura (1997), children observe others in order to learn new behaviour. In this case, the children observe how popular pro-social children behave in some ways and they use this observation to imitate behaviour.

In addition, groups of children who are having pro-social behaviour can create a positive school environment. In this term, school environment includes school in physicall and social dimensions such as; interpersonal relationship between and among peers, teachers, and staffs (Khairiah. 2009). When the children encompass prosocial behaviour tendencies, they may likely have a positive self-concept (Eisenberg, 2006). When they feel good about themselves; they may be able to focus on other's needs because they have fulfilled their own needs. The children may feel that they can assist others since they have some competencies needed in helping others (Eisenberg, 2006). Given this example, they love to help teachers and friends. People around them rely on them whenever difficulties strike such as classmates will always turn to these particular children to seek any help. Moreover, the teachers also can ask them, for example, to socialize school rules and regulations by appointing them as prefects. Since popular pro-social behaviours 
children give positive effects to their peers and school, it is worth conducting this study in order to get a clear description of popular pro-social behaviour among children in the school and the effects

\section{METHOD}

This study used mixed method research design. This research design was applied to collect data from quantitative and qualitative analysis. As defined by Brewer and Hunter (1989) in Creswell (2005, p. 510), a mixed research method is "a procedure for collecting, analysing, and mixing both quantitative and qualitative data in a single study to understand a research problem." The use of mixed method research design in this study aimed to build on the strengths of both quantitative and qualitative data (Creswell, 2005).

Furthermore, Punch (2009, p. 290) clarified that:

....quantitative research brings the strength of conceptualizing variables, profiling dimensions, tracing trends and relationship, formalizing comparisons and using large and perhaps representative sample. On the other hand, qualitative research brings the strengths of sensitivity to meaning and to context, local groundedness, the in-depth study of smaller samples, and great methodology flexibility which enhances the ability to study process and change.

With the combinations of two strengths from quantitative and qualitative, it is hoped that the results of the study provide a rich context for a more comprehensive research, particularly in psychology research (Gelo, Brakkmann, and Benetka, 2008).

In Mixed method research, there are three (3) types of design, namely: (1) triangulation mixed method design, (2) explanatory mixed method design (quantitative data/results followed up by using qualitative data/results), and (3) exploratory mixed method design (qualitative data/results used to build quantitative data/results) (Creswell, 2005). In this study, the researcher used explanatory mixed method design where quantitative data was collected first and then it was followed up by collecting qualitative data. The first quantitative data was used to get a general idea of the research problem: more understanding or explanation of the research problem was obtained from qualitative data (Creswell, 2005).

\section{METHODS OF DATA COLLECTIONS}

The sample included 360 of Grade 5 students $(\mathrm{N}=360,186$ girls, 174 boys ) from three private primary schools, namely: Sekolah Dasar Swasta (SDS) Angkasa 3, Sekolah Dasar Swasta Angkasa (SDS) Angkasa 4, and Sekolah Dasar Swasta Angkasa (SDS) Angkasa 9. These schools are under "ARDHYA GHARINI" foundation, an organization that is owned by Indonesia Air Force Army. All of the schools are located in the same area of Halim Perdana Kusuma, Jakarta Timur. Even though the schools are owned by Indonesia Air Force, the students who are studying are not only from air force army children. The schools are also opened for public. Most of the students come from the high income community.

\section{Socio-metric status of Peer Nomination}

In this study, socio-metric status of peer nomination is adapted from Behavioural, Social, and Emotional Assessment of Children and Adolescents (Merrel, 1999). This assessment can be administered for children who have good skills in reading and writing (Merrel, 1999). Furthermore, according to Parke and Gauvain (2009), there are three (3) reasons for choosing children as the main source in providing data of children' peer status. First, as part of peers, they see more types of the relevant behaviour than adults. Second, they have interacted and experienced with each other. Third, data is collected from many individuals, so that there will be no dominating view.

In this present study, the students were given peer matrix of peer nomination, then, they were asked to write a student's name on each item to whom they think the item applied. Each child could nominate his/her peer more than once and he/she could write 
his/her peer's name as much as they could do per item. Scoring of peer nomination was obtained by totalling the number of nominations that each child got. The highest five nominations were considered as popular children.

Merrel's peer matrix (1999) assessed two nominations; positive and negative nomination. Positive nominations are used to indicate high social status in the class which was associated with popular pro-social behaviours. Meanwhile, negative nominations were usually associated with low social status and anti-social behaviour. Since the researcher only wanted to get data of popular pro-social behaviours children, the researcher only employed positive items in this study. The peer matrix of peer nomination consisted of 7 items: (1) Whom would you like most to be your best friend?, (2) Whom would you like to invite over to your home?, (3) Who has many friends in the class?, (4) Who likes to help his/her friends?, (5) Who is always appointed as leader in the class?, (6) Who always gets good scores in the class?, (7) Who likes to help teachers?, and (8) Who gets along well with the teachers?.

\section{$\underline{\text { Subjects }}$}

There were two types of participants who took part in this qualitative study. First, there were 5 children who participated in an interview from each class of Grade 5. They were chosen based on systematic sampling. In this sampling, the preferred sample size was obtained by choosing every nth individual or site in the population (Creswell, 2005). Since there were 10 classes of Grade 5 which was from three different schools, total participants in interview were 50 children. Second, homeroom teachers of Grade 5 also participated in the interview. There were 10 homeroom teachers altogether.

\section{Methods of Data Collection \\ (a) One-on-One Interviews}

In order to get a detailed description of the phenomenon, the researcher decided to carry out one-on-one interview. The interviews were conducted for both homeroom teacher of Grade 5 primary school and the children. The children were asked 11 questions based on peer matrix of nomination that was previously done. The objective of this interview was to gain information regarding popular children based on peers and homeroom teachers.

\section{RESULT AND DISCUSSION}

Peer matrix of peer nomination adapted from Merrel (1999) was used in order to identify the popular children of Grade 5. All Grade 5 children were given a set of questions and they were asked to write other student's name on each item to whom they think applied. Scoring of peer nominations were obtained by totalling the number of nominations that each child received. The highest five nominations were considered as popular children.

The schools involved in this study were Sekolah Dasar Swasta Angkasa 3, Sekolah Dasar Swasta Angkasa 4, and Sekolah Dasar Swasta Angkasa 9. However, only Grade 5 students took part as participants. In SDS Angkasa 3, there were two classes of Grade 5; Grade 5 A and 5 B. Grade V 5 consisted of 22 students that comprised of 15 girls and 7 boys, meanwhile there were 26 students of Grade 5 B that consisted of 14 girls and 12 boys. SDS Angkasa 4 and SDS Angkasa 9 had four classes of Grade 5. In SDS Angkasa 4, Grade 5 A had 39 students that comprised of 19 girls and 20 boys. Grade 5 B had 38 students that consisted of 21 girls and 17 boys. Meanwhile, Grade $5 \mathrm{C}$ had 37 students, included 20 girls and 17 boys. Grade 5 D consisted of 43 students that comprised of 19 girls and 19 boys. In SDS Angkasa 9, there were 21 girls and 20 boys, altogether 41 students. Grade 5 B had 40 students that comprised of 18 girls and 22 boys. The next classes were Grade 5 C and Grade 5 D. Grade $5 \mathrm{C}$ had 39 students that consisted of 19 girls and 20 boys. However, Grade 5 D had 40 students that comprised of 20 girls and 20 boys. From 360 Grade 5 students who participated in peer matrix of peer nomination, there were 11 students who did not take part since they were absent on that 
day. These eleven students were 2 students of SDS Angkasa 3, 4 students of SDS Angkasa 4, and 5 students of SDS Angkasa 9.

From the results of peer matrix of peer nomination, it was found that there were five (5) popular children in each class of Grade 5 in SDS Angkasa 3, SDS Angkasa 4, and SDS Angkasa 9. Five popular children were based on top five nominees in peer nomination. These children became popular because they got high nominations from his/her peers. The popular children of SDS Angkasa 3, 4, and 9 comprises of 27 girls and 23 boys. The results of popular children in SDS Angkasa 3, SDS Angkasa 4, and SDS Angkasa 9 can be described in table as follow;

Over the past 70 years, an abundance of research on popularity and children has been conducted. Most of the researchers use sociometric assessment procedure to get information of peer status on children (Merell, 1999). According to Coie, Dodge, and Coppetilli (1982), there are five social statuses of children; Popular, rejected, neglected, controversial, and average. Popular children are liked most and few disliked by peers (Coie et al., 1982). Bagwell (2004) stated that there is relationship between popularity and friendship. The aspect of liking on popular children facilitate acceptance in peer groups, and reciprocal liking was form of friendship. Furthermore, Park \& Gauvain (2009) related peer acceptance on children' social development. They found that peer acceptance can provide positive experience for the children as underpinning for healthy adult social behaviours.

In this study, five popular children were identified by using positive items in peer nomination and positive items referred to pro-social behaviours. According to Greener (2003), popular children were significantly to have high level of pro-social behaviours compared to other groups. The result of peer nomination and teachers' assessment showed the same results in her study (Greener, 2003). In addition, the result of prior study found children who were popular sociometrically engaged in pro-social behaviours (Coie et al., 1982; Newcomb et al., 1993; Greener, 2003;
Rubin et al., 2006) which was consistent with the findings of present study.

Moreover, two research questions were answered in this study. They were; RQ 1. What are the effects of popular pro-social children on peers?, and RQ 2. What are the effects of popular pro-social children on school environment?. However, the presentation of the result was combined since the same interview questions were asked both for the children and homeroom teachers.

Based on children, popular pro-social children gave effects on peers and school environment in term of pro-social behaviour, leadership, and academic achievement. Homeroom teachers too said that popular pro-social children gave effects on peers and school environment with their pro-social behaviour and academic achievement. At this point, children and homeroom teachers had the same opinion: pro-social behaviour and academic achievement as the effects of popular pro-social children. The description of the effects popular pro-social children have on peers and school environment are as follow;

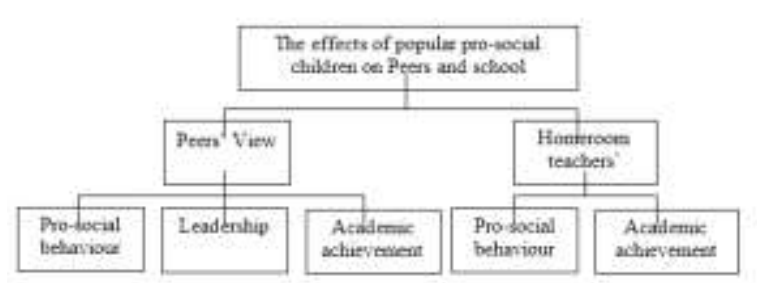

Figure 1: The effects of popular pro-social children on peers and school environment based on peers and homeroom teachers

From the results of the study, it was found that popular pro-social children were accepted and liked by their peers. According to Howes and Tonyan (1999), the aspect of liking popular pro-social children put them in high status of liking profile among peers. The acceptance and liking mostly resulted from their pro-social behaviour. Since they engaged in pro-social behaviour, peers wanted popular pro-social children as their best friends. In other words, popular prosocial got nominations as best friends most wanted. These results were consistent with previous studies that popular children were 
liked because of their pro-social actions (Coie et al., 1982; Newcomb et al., 1993; Rubin et al., 2006) and they were best friends' nominated (Newcomb et al., 1993).

According to peers, popular pro-social children were also known as good children. Good children in this study referred to being kind, helpful, and nice to others. As helpful children, popular pro-social children liked to help peers and teachers. They gave help in many ways, for instance, they helped their peers when they were sick, and helped teachers by bringing their books to the office. In pro-social term, popular pro-social children offered practical help to peers and teachers. However, there was gender difference in practical help. Some of peers said that popular pro-social boys liked to help more compared to popular pro-social girls.

Furthermore, popular pro-social children expressed their sharing and caring more than their peers. They liked to share especially things and knowledge. In sharing knowledge, popular pro-social children offered academic help to their peers. Popular pro-social children could provide academic help because they had high academic achievement. They explained what they knew to their peers who did not understand the lessons. This behaviour showed that popular pro-social children had positive effects on school environment in general, especially on peers.

As leaders, popular pro-social children were chosen because they had the attributes of leadership. These attributes of leadership made them got high nominations as leaders. Having pro-social behaviours and excellent academic achievement were two attributes that related to leadership. This result supported a study conducted by Coie et al., (1982) stated popular children got high nominations as pro-social children and leader. In other words, we can say that prosocial behaviour and leadership qualities can be found on popular children. Coie et al., (1982) stated that popular children got high scores as leaders and this study has proven it. Another study done by Lease et al. (2002) showed that popular children have social prerogatives, one of them is leadership.
Based on peers, popular children became leader because they won in voting, in other words, they got high nominations as leader. There were several reasons why popular children were chosen as leaders; (1) popular children were involved in pro-social behaviours; (2) they were intelligent children so they had good academic achievement, (3) they had good personalities and were good in physical condition, and (4) they had charisma. The attribute of pro-social behaviour on popular children are significantly related to leadership of popular children. Accordingly, at the age of 9-11, children tend to choose leader who are actively involved in pro-social behaviour. When the leaders are pro-social children, peers have the tendency to development of pro-social behaviour as well (Eisenberg et al., 2006). In addition, according to Eisenberg and Mussen (1989), peers can be effective agents of reinforcement that facilitate the acquisition and modification of pro-social behaviour. Previous research found that children give positive responses to peers 'pro-social behaviour quite often (Eisenberg et al., 1981 in Eisenberg \& Mussen 1989, p. 96) and the finding of this study somehow is in line with that result.

Moreover, it was interesting to note that peers mentioned popular pro-social leaders had charisma. The word of charisma was introduced by Weber (1922/1963). He suggested, "charismatic leaders as being extremely highly esteemed persons, who are gifted with exemplar qualities" (Bass, 1990). In the present study, peers stated that popular children have their own ways to become a leader and they had followers as well. It indicated that popular children had charisma that could not be explained by their peers. Having charisma for popular children gave them chance to influence peers. Peers saw them as figures that had to be followed- what they said or what they did. When charismatic popular leaders were pro-social behaviour children, the followers were influenced to be pro-social as well. As followers, peers followed what their leaders said. Given this example, popular pro-social leaders told their friends not to fight and to keep the class 
conducive for teaching and learning process. At this part, popular pro-social leaders played their important roles and led their peers toward positive actions. When the environment of the class was supporting the teaching learning process, it gave effect on school environment in general.

Based on homeroom teachers' views, popular pro-social children affect on peers with their pro-social behaviour and academic achievement. Pro-social behaviour of popular pro-social children was helpful. They like giving help, especially academic help. According to homeroom teachers, popular pro-social children could give academic help because they had high academic achievement. However, achievement was not only in academic, most of homeroom teachers agreed that popular pro-social children had non- academic achievement as well. Since popular pro-social children had many achievements, they were chosen to represent school in competitions or events inside and outside the school. By representing the school, popular pro-social gave positive contributions to the school.

With all capabilities and willingness in offering academic help, it seemed that popular pro-social behaviour played its role to upgrade peers and mentored them in learning. Referring to Vygotsky'theory of ZPD (1962), it was hoped that there was a transfer of knowledge from more skilled peers to unskilled peers in order to achieve goals in academic learning (Santrock, 2010).

Thus, it is believed that popular prosocial children give effects on peers by giving assistance and motivation in learning and on a large scale they contributed to the success of teaching and learning process at school.

Peers said that popular pro-social children were clever. They had positive academic behaviours. Given this example, peers said that they liked to study and read. The findings were consistent with the findings of Meijs et al. (2010), de Bruyn \& Cillessen (2006), and Rodkin et al. (2000). These result indicated that popular pro-social children had academic competence which responded to the study of Wentzel (1991). With these combinations, popular pro-social children got high academic achievement. Homeroom teachers added that popular prosocial children were appointed to represent the school because of their academic achievement. Actually, this finding is not new in the study of popularity and academic achievement. Research has linked popularity with pro-social behaviour and academic achievement on Chinese Hong Kong adolescents (Ma et al., 1996), and popularity, academic achievement and social intelligence (Meijs et al., 2010). In addition, LaFontana and Cillessen (1999) found that there is positive relation between sociometric popularity and academic achievement.

Overall, the results indicated that popular pro-social behaviours influence peers and school environment directly and non- directly. The findings suggested that all the effects were positive. Popular pro-social children gave effects on peers and school by their pro-social behaviours. They were known as helpful children and they liked to offer academic and practical help. As leaders, popular pro-social children had responsibilities and they tended to motivate their peers to fulfil their own responsibility as student. Since they had qualities as leaders, popular pro-social children were able to encourage their peers to positive developmental outcomes. By having academic achievement, popular pro-social behaviours could give good example of being good students which were excellent academically and non- academically but they still had positive interaction with peers. In addition, it was supported by homeroom teachers when they were asked to give their opinions whether popular-pro-social children give effects on peers and school environment. All the homeroom teachers agreed that popular pro-social children gave effects on their peers and school environment.

Moreover, this study also attempts to relate the effects of popular pro-social children by using social learning theory. According to Bandura (1997), children learn new behaviours by doing observation. The children observe other children in order to get an idea how new behaviours are performed. Then, this information will be used in guiding 
the children to behave. Popular pro-social children are liked by peers, they are prosocial, they have good academic achievement, they are leaders and they have good quality relationship with peers and teachers. Thus, popular children become a modelled behaviour. Peers observe them in order to acquire positive behaviour.

\section{CONCLUSION}

This study began by collecting data of popular children using peer matrix of peer nomination adapted from Merell (1999). As suggested by previous research on popularity, clearly popular sociometric children were liked by their peers. The positive items used in this study proved that popular children were related to peers' best friends, pro-social behaviours, leadership, and academic achievement. The use of interviews was aimed to get more evidences in order to have better understanding of this study. Two types of participants, namely; peers and homeroom teachers gave unique views on popular children. Both views, however, described popular sociometric children positively. It seemed that the application of mixed methods in this study made the results obtained more fruitful.

Obviously, popular pro-social children affect peers and school environment. The results of the study revealed that the effects were on pro-social behaviour, leadership and academic achievement. This can be explained by using social learning theory proposed by Bandura (1997). As modelled behaviour, popular children are observed by their peers and then peers use the information to lead them in the acquisition of new behaviours. Since the model is popular pro-social behaviour, the behaviour acquired are prosocial as well. When children have pro-social behaviour, they affect the school environment. It can create positive environment for teaching and learning process. Other results obtained from the interview are from homeroom teachers. In general, there are similarities in viewing popular children, such as pro-social behaviours and academic achievement on the effects of popular pro-social children.
In order to have more literature on popularity and pro-social behaviours, it is needed to investigate popular pro-social behaviours children cross age dimensions in order to find out the pattern of popularity at different ages. The same study could be conducted at different setting, for example at public schools. The result might be different in term of factors affect the acquisition of pro-social behaviours since the children come from different background of socioeconomic status and culture where the school is- urban or rural. It is also needed to do research on popular pro-social and antisocial children is in line with the effects of popular pro-social and anti-social children on peers and school.

\section{REFERENCES}

Bandura, A. (1997). Social learning theory. New Jersey: Prentice Hall.

Bagwell, C. L. (2004). Friendships, peer networks, and antisocial behaviour. In J. B. Kupersmidt \& K. A. Dodge (Ed.), Children's peer relations: from development to intervention. Washington: American Psychological Association.

Birch, S. H., Ladd, G. W. (1996). Interpersonal relationships in the school environment and children early school adjustment: the role of teachers and peers. In J. Juvonen \& K. R. Wentzel (Eds.), Social motivation: understanding children school adjustment. New York: Cambridge University Press.

Coie, J. D., Dodge, K. A., \& Coppotelli, H. (1982). Dimensions and types of social status: across- age perspectives. Journal of Developmental Psychology, Vol. 18, No. 4, pp. 557-570.

Creswell, J. W. (2005). Educational research: planning, conducting, and evaluating quantitative and qualitative research. USA: Pearson. 
De Bruyn, E. H., Cillessen, A. H. N. (2006). Heterogeneity of girls'consensual popularity: academic and interpersonal behavioural profiles. Journal of Youth and Adolescence, vol. 35, No. 3, June 2006, pp. 443445.

Eisenberg, N., Fabes, R. A., \& Spinrad, T. L. (2006). Prosocial development. In W. Damon \& R. M. Lerner (Ed.) \& N. Eisenberg (Vol., Ed.), Handbook of child psychology: Vol. 3. Social, emotional, and personality development (6th Edn.). New York: Wiley.

Gelo, O., Braakman, D., Benetka, G. (2008). Quantitative and qualitative research: beyond the debate. Integr Psych Behav. 42, 266-290.

Eisenberg, N., Mussen, P. H. (1989). The roots of prosocial behaviour in children. In M. L Hoffman (Ed.). Cambridge studies in social \& emotional deleopment. United Kingdom: Cambridge University Press.

Greener, S. H. (2000). Peer assessment of children's prosocial behavior. Journal of Moral Education, Vol. 29, No. 1.

Howes, C., Tonyan, H. (1999). Peer relations. In Balter, L., Tamis -Le Monda, C. S. (Eds.). Child psychology. A handbook of contemporary issues. USA: Edwards Brother.

Khairiah, (2009). The relationship between school environments and emotional intelligence of students in secondary school in rural Selangor: a case study (Master's thesis). IIUM, Malaysia.

LaFontana, K. M., Cillesen, A. H. N. (1999). Children's interpersonal perception as a function of sociometric and peer-perceived popularity. The Journal of Genetic Psychology, 160(2), pp. 225-242.

Lease, A. M., Kennedy, C. A., \& Axelrod, J. L. (2002). Dimensions of social status in preadolescent peer groups: likability, perceived popularity, and social dominance. Social Developemnet, 11, 4, pp. 509-533.

Ma, H. K., Shek, D. T. L., Cheung, P. C., Lee, R. Y. P. (1996). The relation of prosocial and antisocial behaviour to personality and peer relationships of Hong Kong Chinese adolescents. The Journal of Genetic Psychology, 157 (3), pp. 225-266.

Meijs, N., Cillessen, A. H. N., Scholte, R. H. J., Segers, E., Spijkerman, R. (2010). Social intelligence and academic achievement as predictors of adolescent popularity. Journal of Youth Adolescence 39: 62-72.

Merell, K. W. (1999). Behavioral, social and emotional assessment of children and adolescents. New Jersey: Lawrence Eribaum Associates.

Newcomb, A. F., Bukowski, W. M., \& Pattee, L. (1993). Children peer relations: a meta- analytic

review of popular, rejected, neglected, controversial, and average sociometric status. Psychological Bulletin, Vol. 113, No. 1, pp. 99-128.

Nik Suryani., N. A. R., Suhailah, H., \& Mastura, B. (2008). A practical guide to interviewing in educational research. Selangor: IIUM Printing Sdn. Bhd.

Parker, R. D., Gauvain, M. (2009). Child psychology: a contemporary viewpoint. (7th Edn.), New York: McGraw Hill.

Punc, K. F. (2009). Introduction to research methods in education. London: Sage Publications Ltd.

Rodkin, P. C., Farmer, T. W., Pearl, R., \& Van Acker, R. (2000). Heterogeneity of popular boys: antisocial and prosocial configurations. Developmental Psychology, Vol. 36, No. 1, pp. 1424.

Rubin, K. H., Bukowski, W. M., \& Parker, J. G. (2006). Peer interactions, relationships, and groups. In W. Damon \& R. M. Lerner (Ed.) \& N. Eisenberg (Vol., Ed.), Handbook of 
child psychology: Vol. 3. Social, emotional, and personality development (6th Edn.). New York: Wiley.

Rys, G. S., Bear, G. G. (1997). Relational aggression relations: gender and developmental issues. MerrilPalmer Quarterly, January 1997, Vol. 43, No. 1, pp. 87-106.

Santrock, J. W. (2010). Child development. (12th edn.). New York: McGrawHill.

Wentzel, K. R. (1991). Relations between social competence and academic achievements in early adolescence. Child Development 62, pp. 10661078.

Xie, H., Boucher, S. M., Hutchins, B. C., \& Cairns, B. D. (2006). What makes a girl (or a boy) popular (or unpopular)? African American children's perception and developmental differences. Developmental Psychology, 00121649, 2006, Vol. 42, Issue 4.

Young, L. L., Cooper, D. H. (1944). Some factors associated with popularity. Journal of Educational Psychology, Vol. XXXV, December 1944, No. 9, pp. 513-534. 